Jurnal Teknik Komputer AMIK BSI

Volume 7, No.1, Januari 2021

P-ISSN 2442-2436, E-ISSN: 2550-0120

Akreditasi Ristekdikti, No: 36/E/KPT/2019 (Sinta 4)

DOI: $10.31294 /$ jtk.v4i2

\title{
Rancang Bangun Sistem dan Kontrol Penggunaan Air PDAM Secara Realtime Berbasis Wemos dan IoT
}

\author{
Reza Diharja ${ }^{1}$, Bobby Setiawan ${ }^{2}$, Wike Handini ${ }^{3}$ \\ 1,2,3 Prodi Teknik Elektro, Fakultas Teknologi Industri, Universitas Jayabaya \\ 1e-mail: reza.diharja@jayabaya.ac.id \\ 2e-mail: bobby.setiawan.xi.ipa@gmail.com \\ ${ }^{3}$ e-mail: wihanni@gmail.com
}

\begin{tabular}{ccc}
\hline Diterima & Direvisi & Disetujui \\
$27-11-2020$ & $23-12-2020$ & $24-01-2021$ \\
\hline
\end{tabular}

\begin{abstract}
Abstrak - Air bersih sangat penting bagi kehidupan manusia. Penggunaan air bersih yang disuplai dari PDAM harus tetap dalam pengawasan karena menyangkut hajat hidup orang banyak. Sistem ini dibuat dengan tujuan untuk mengetahui dan mengendalikan jumlah air bersih yang terpakai. Pemantauan serta pengendalian penggunan air bersih dapat dilakukan dari jarak jauh karena sistem berbasis IoT (Internet of Things). Perangkat IoT yang digunakan antara lain MIT App inventor untuk membuat aplikasi Android, Firebase dan WeMos D1 ESP8266. Terdapat dua sensor utama pada sistem yaitu sensor $\mathrm{pH}$ dan flowmeter dengan tujuan masisng-masing untuk karakterisasi dan mengetahui volume air. Pengguna menetapkan nilai setpoint volume air yang akan digunakan selanjutnya pada aplikasi akan menampilkan data berupa tulisan "usage" atau penggunaan beserta tarif air dalam satuan Rupiah. Hasil pengujian lainnya diterapkan pada sensor $\mathrm{pH}$ yang mana pada kasus ini ditujukan untuk karakterisasi berbagai macam fluida dengan $\mathrm{pH}$ yang beragam. Sensor $\mathrm{pH}$ yang digunakan sangat tepat diterapkan untuk tujuan pemantauan kualitas air bersih sehingga nilai derajat keasaman pun ditampilkan pada layar aplikasi. Nilai error rata-rata antara volume air aktual dengan volume air sesuai setpoint (penetapan) adalah sebesar 1,29\%. Meskipun nilai eror tersebut tergolong kecil namun kedepannya harus bisa semakin mendekati error sama dengan nol.
\end{abstract}

Kata Kunci: Air, Internet of Things, Sistem dan Kontrol

\begin{abstract}
Clean water is very important for human life. The use of clean water that is supplied by PDAM must be kept under supervision because it involves the livelihoods of many people. This system was created with the aim of knowing and controlling the amount of clean water used. Monitoring and controlling the use of clean water can be done remotely because of the IoT-based (Internet of Things) system. The IoT devices include the MIT App inventor to create Android application, Firebase as a cloud database and WeMos D1 ESP8266 microcontroller. There are two main sensors in the system, $\mathrm{pH}$ sensor and flowmeter, each of sensor aims to characterize and determine the volume of water. The user sets the water volume setpoint value which will be used later in the application and will display the data in the form of $r$ usage along with the water tariff in Rupiah. Other test results are applied to a $\mathrm{pH}$ sensor which in this case is intended to characterize various kinds of fluids with various pHs. The $\mathrm{pH}$ sensor used is very precisely applied for the purpose of monitoring clean water quality so that the value of the degree of acidity is displayed on the application screen. The average error value between the actual water volume and the volume of water according to the setpoint is $1.29 \%$. Even though the error value is relatively small, in the future it should be closer to the error equal to zero.
\end{abstract}

Keywords: Control and system, Internet of Things, Water

\section{PENDAHULUAN}

Air bersih merupakan kebutuhan primer manusia, digunakan untuk minum, mandi, mencuci MCK dan lain sebagainya. Salah satu penyedia air bersih untuk kebutuhan manusia di masyarakat adalah PDAM (Perusahaan Daerah Air Minum) yang juga bertanggungjawab dengan kualitas air yang diproduksinya. Menurut data yang dipublikasikan pada (Amanda, 2019), sekira 2,7 miliar masyarakat dunia termasuk Indonesia di dalamnya, berpotensi mengalami kekeringan dengan tingkat yang paling parah. Oleh karena itu, penting sekali bagi masyarakat untuk memerhatikan penggunaan air 
bersih menjadi lebih hemat. Hal ini bertujuan agar ketersedian air bersih dapat berlangsung dalam waktu yang lama.

Sustainable Development Goals (SDGs) 2030 telah menetapkan sebuah upaya untuk mencapai tujuan pembangunan berkelanjutan (TPB) terhadap akses air bersih khususnya air minum. Air bersih yang layak minum harus memenuhi kriteria sebagai berikut: aman; berasal dari sumber air yang layak, berada di dalam atau di halaman rumah, dapat diakses setiap saat dibutuhkan, dan kualitasnya memenuhi standar kesehatan. Diperkirakan saat ini akses air minum aman di Indonesia baru mencapai 6,8\% dari total rumah tangga yang ada (Purwanto, 2020).

Salah satu parameter penting untuk mengetahui kualitas air bersih adalah dengan mengetahui nilai derajat keasamannya atau $\mathrm{pH}$. Selain menandakan tingkat nilai derajat keasaman, $\mathrm{pH}$ dapat berubah jika terkontaminasi bahan-bahan kimia sehingga menjadikan $\mathrm{pH}$ sebagai indikator penting pada kualitas air. Sesuatu yang diukur oleh $\mathrm{pH}$ pada air adalah jumlah ion hidrogen dan hidroksil bebasnya. Air yang memiliki jumlah ion hidrogen bebas lebih banyak, menandakan sifatnya adalah asam. Sebaliknya, jika ion hidroksil bebasnya lebih banyak, maka air akan bersifat basa (USGS, 2019).

Agar pemantauan terhadap kualitas dan penggunaan air lebih realistis dan terukur, maka perlu dibuat sebuah sistem yang mampu mengetahui kedua parameter tersebut. Pemantauan kualitas air dapat dilakukan dengan bantuan sensor $\mathrm{pH}$ sedangkan banyaknya penggunaan air dalam satuan liter dapat diketahui dengan menggunakan sensor flowmeter. Sensor $\mathrm{pH}$ merupakan sensor yang dilengkapi dengan probe ukur, di mana probe tersebut yang bersentuhan langsung dengan air. Luaran dari sensor $\mathrm{pH}$ adalah sinyal listrik dengan satuan tegangan (Volt) yang nilainya dapat dikonversi menjadi derajat keasaman atau $\mathrm{pH}$.

Penerapan sensor $\mathrm{pH}$ untuk memantau kualitas air telah dilakukan oleh (Barus, Ch Louk, \& Pinggak, 2018) yang mana mereka menerapkannya pada akuarium. Sedangkan penggunaan sensor flowmeter telah dilakukan oleh (Br Pelawi \& Manan, 2016) dengan tujuan untuk mengetahui banyaknya volume air pada sistem pemurnian air. Penggunaan sensor $\mathrm{pH}$ dan flowmeter yang disambungkan ke mikrokontroler WeMos pernah digunakan dalam penelitian yang dilakukan oleh (Setiadi \& Abdul Muhaemin, 2018). Mereka menggunakan sensorsensor tersebut untuk diterapkan pada sistem irigasi cerdas.

Mikrokontroler WeMos dapat terkoneksi dengan jaringan internet untuk mengimplementasikan Internet of Things (IoT). IoT merupakan suatu bentuk revolusi internet yang dapat dikatakan sebagai pemberontakan dunia internet. IoT didefinisikan dalam banyak pengertian, mencakup berbagai aspek di kehidupan manusia mulai dari penggunaan di rumah, perkotaan, kendaraan hingga perangkat yang dapat mengumpulkan data-data personal manusia dan menggunakan data-data tersebut untuk tujuan bisnis (Mondal, 2019). Data yang dikumpulkan oleh mikrokontroler selanjutnya dikirim ke Firebase. Di sini, data disimpan secara realtime dan dapat diakses melalui aplikasi Android. Aplikasi Andriod dibuat dengan menggunakan MIT App Inventor yang dapat dikostumisasi sesuai dengan kebutuhan pengguna. Nilai penggunaan air yang telah dikonversi menjadi biaya dalam satuan Rupiah dilakukan di aplikasi Android.

\section{Sensor pH E-210-C}

Merupakan sebuah alat ukur derajat keasaman atau $\mathrm{pH}$ meter berbasis elektronik. Digunakan untuk mengukur derajat keasaman benda berfasa cair. Alat ukur berbentuk modul yang dilengkapi dengan probe terhubung dengan rangkaian pengkondisi sinyal. Probe mengukur beda potensial pada cairan dengan membandingkan nilai pengukuran dari elektroda kerja dan elektroda referensi. Sedangkan pengondisi sinyal merupakan bagian dari pre-amplifier yang memiliki impedansi input yang tinggi. Luaran preamplifier dalam bentuk sinyal yang dapat diolah dan dianalisis. Pre-amplifier menjadikan sinyal pengukuran lebih stabil dan kuat terhadap pengaruh gangguan derau.

Tabel 1. Relasi Antara pH dengan Tegangan

\begin{tabular}{|c|c|c|}
\hline No & $\begin{array}{c}\text { Derajat } \\
\text { Keasaman } \\
(\mathrm{pH})\end{array}$ & $\begin{array}{c}\text { Tegangan } \\
(\mathrm{V})\end{array}$ \\
\hline 1 & 4,01 & 4,82 \\
\hline 2 & 6,86 & 4,02 \\
\hline 3 & 9,18 & 3,35 \\
\hline
\end{tabular}

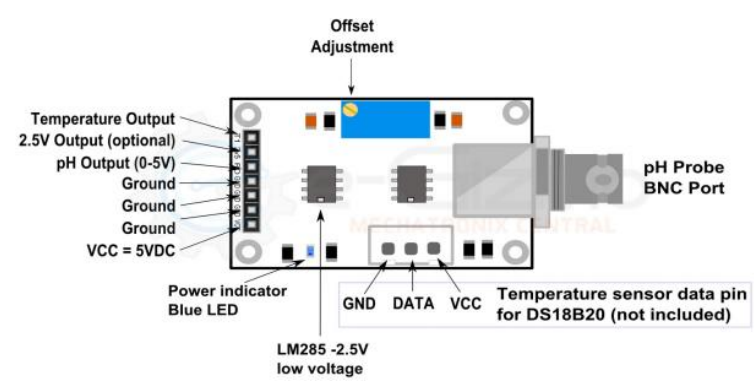

Gambar 1. Modul Sensor PH EC-201-C

\section{Flowmeter}

Debit maupun laju aliran air/fluida dapat diukur dengan menggunakan sensor flowmeter. Nilai debit pada fluida yang mengalir dapat diketahui dari turbin yang ikut berputar karena mengikuti aliran fluida (Aryanto, 2019). Sensor flowmeter memanfaatkan efek Hall dalam pengoperasiannya dan luarannya 
dalam bentuk pulsa listrik berfrekuensi proporsional dengan banyaknya putaran/rotasi dari turbin. Dengan menggunakan relasi debit dan pulsa frekuensi, maka laju aliran air dapat diketahui nilainya.

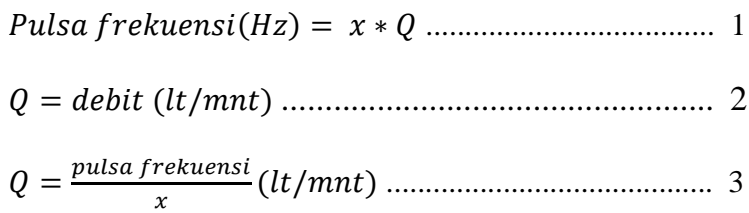

Atau dengan kata lain,

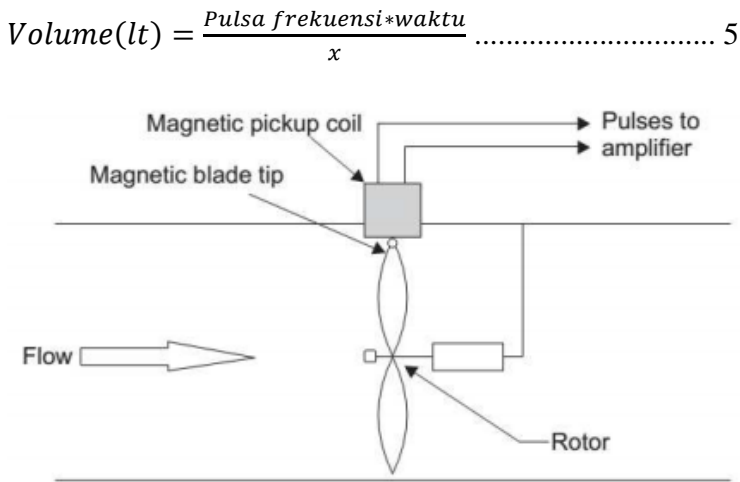

Gambar 2. Desain Skematik Sensor Flowmeter (Arief Rachman Hakim, Budijanto, \& Widjanarko, 2018)

Sensor berbasis efek Hall merupakan sensor yang memanfaatkan respon medan magnet. Penggunaan sensor berbasis efek Hall umumnya terdapat pada tujuan penentuan posisi, switching proximity, mengetahui nilai kecepatan dan pengukuran arus listrik.

\section{WeMos D1 R2 Mini}

Mikrokontroler berbasis ESP8266 yang dapat terkoneksi dengan Wi-fi 802.11 dan dapat diprogram menggunakan Arduino IDE. Secara sekilas, terlihat mirip dengan Arduino UNO dapat menggunakan shield Arduino UNO dan beberapa sensor yang kompatibel dengannya (Rudiansyah, Mardiono, \& Diharja, 2020).

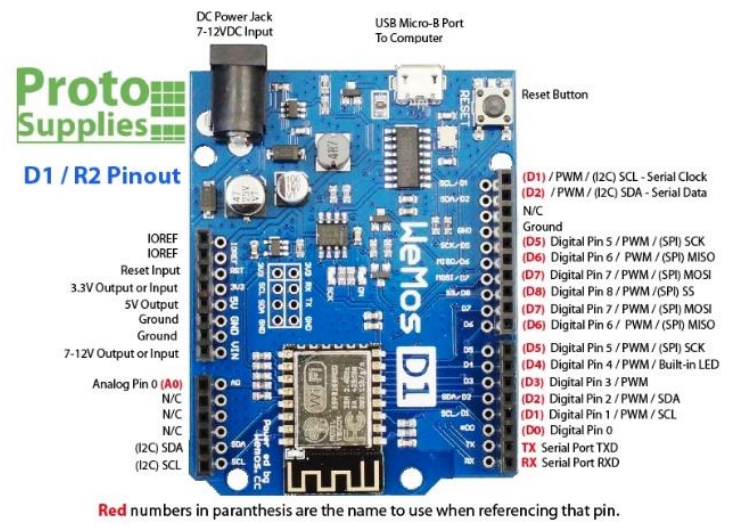

Gambar 3. Tampak atas board Wemos D1 Mini
(Supplies, 2020)

\section{Firebase}

Sebuah tempat hosting berbasis awan (cloud) bukan seperti NoSQL yang menggunakan model dokumen. Merupakan aplikasi yang dapat digunakan sebagai tempat untuk mengakses banyak devais aplikasi elektronik khususnya aplikasi pada smartphone. Firebase merupakan bagian dari infrastruktur Google yang mana memiliki ukuran yang akan semakin besar seiring dengan berjalannya waktu.

Tidak seperti fungsionalitas pada database NoSQL, Firebase memuat fungsi analisis, autentikasi, monitoring performa, pemesanan hingga laporan kerusakan. Menggunakan Firebase dapat menghemat waktu karena dimungkinkan mengelola sedikit integrasi dalam aplikasi. Hal tersebut dapat terjadi karena Firebase memiliki API intuitif dikemas dalam satu paket SDK.

\section{MIT App Inventor}

Merupakann sebuah aplikasi/tools berbasis awan digunakan untuk membuat aplikasi android dan dikembangkan oleh MIT USA. MIT App Inventor berbasis visual block programming yang berarti dapat membuat aplikasi tanpa menulis kode. Pembuatan aplikasi berdasarkan perintah maupun event handler yang diatur dengan drag and drop blocks. App Inventor tidak hanya untuk membuat suatu aplikasi, mit app inventor dapat digunakan untuk mengasah logika, seperti halnya menyusun sebuah puzzle. MIT App Inventor dibangun untuk pemula yang mulai belajar membuat aplikasi android (Satriya, Mardiono, \& Diharja, 2020)

\section{Solenoid Valve}

Sebuah solenoid valve terdiri dari dua komponen utama, yakni rumah solenoid dan komponen solenoidnya. Solenoid bekerja dengan memanfaatkan kumparan induktif yang diberikan sinyal elektromagnetik. Dalam keadaan normal, sebuah solenoid dapat berkeadaan NO maupun NC. Pada keadaan de-energized, katup yang NO akan terbuka dan sebaliknya. Ketika arus melewati solenoid, kumparan akan berenergi menyebabkan adanya medan magnet. Induksi medan magnet akan menarik plunger, memindahkannya dan memuat pegas tertarik. Jika katup dalam keadaan NC, plunger akan berada di atas sehingga sil membuka pipa orifice dan menyebabkan fluida dapat mengalir. (Tameson, 2020) 


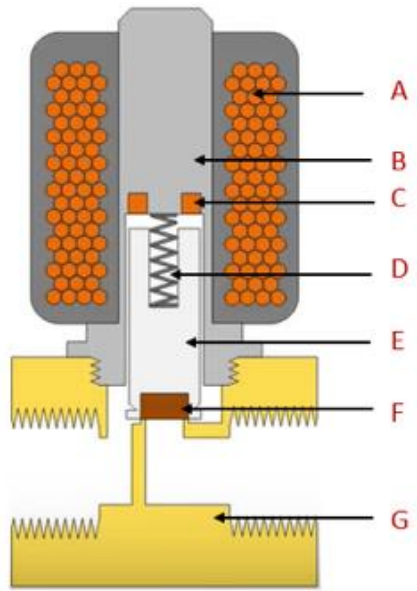

Gambar 5. Komponen pada solenoid valve, Kumparan (A); Armature (B); shading ring (C); pegas $(\mathrm{D})$; plunger $(\mathrm{E})$; sil $(\mathrm{F})$; rumah solenoid $(\mathrm{G})$

\section{Kualitas Air Berdasarkan Nilai Derajat Keasaman}

Air bersih adalah air yang jernih, tidak berwarna, tidak berbau, tidak berasa, dan tidak mengandung mineral/kuman yang membahayakan tubuh seperti disebutkan pada Peraturan Menteri Kesehatan Republik Indonesia No. 416/MENKES/PER/ IX/1990 tentang Syarat-syarat dan Pengawasan Kualitas Air. Sedangkan nilai derajat keasaman sangat berpengaruh terhadap daya racun bahan pencemaran dan kelarutan beberapa gas, serta menentukan bentuk zat di dalam air. Nilai derajat keasaman atau $\mathrm{pH}$ air digunakan untuk mengekspresikan kondisi keasaman dengan rentang nilai antara 1-14. Rentang nilai $\mathrm{pH}$ 1-7 termasuk kondisi asam, $\mathrm{pH}$ 7-14 termasuk kondisi basa, dan pH 7 adalah kondisi netral. Mengacu pada standar baku Peraturan Menteri Kesehatan Republik Indonesia No. 416/MENKES/PER/ IX/1990 kadar pH yang dipebolehkan pada air bersih adalah 6,5-9,0 (Dr. Adhyatma, 1990).

\section{H. Biaya Pemakaian Air PDAM}

Tarif biaya pemakaian air PDAM di Jabodetabek diketahui pada tabel 2 dan digunakan sebagai referensi perhitungan. Banyaknya volume air terukur yang dibaca oleh sensor flowmeter kemudian dikalikan dengan tarif per kubiknya sesuai dengan formulasi (6) berikut:

Total Biaya $(R p)=$ Volume $\left(m^{3}\right) *$ tarif $(R p) \ldots \ldots \ldots . .6$

Tabel 2. Tarif Pemakaian Air PDAM

\begin{tabular}{|c|c|c|c|c|c|}
\hline \multirow{2}{*}{ No } & \multirow{2}{*}{ Gol Tarif } & \multicolumn{4}{|c|}{$\begin{array}{c}\text { Pemakaian dalam meter kubik } \\
\left(\mathrm{Rp} / \mathrm{m}^{3}\right)\end{array}$} \\
\cline { 3 - 6 } & $0-10$ & $11-20$ & $21-40$ & $>40$ \\
\hline 1 & $\begin{array}{c}\text { Sosial } \\
\text { umum (S1) }\end{array}$ & 1,125 & 1,125 & 1,125 & 1,125 \\
\hline 2 & $\begin{array}{c}\text { Sosial } \\
\text { umum (S2) }\end{array}$ & 1,125 & 1,375 & 1,625 & 1,875 \\
\hline
\end{tabular}

\begin{tabular}{|c|c|c|c|c|c|}
\hline 3 & $\begin{array}{c}\text { Rumah } \\
\text { Tangga I } \\
\text { (R1) }\end{array}$ & 1,875 & 2,675 & 3,600 & 4,250 \\
\hline 4 & $\begin{array}{c}\text { Rumah } \\
\text { Tangga II } \\
\text { (R2) }\end{array}$ & 2,300 & 3,250 & 4,250 & 5,100 \\
\hline 5 & $\begin{array}{c}\text { Rumah } \\
\text { Tangga III } \\
\text { (R3) }\end{array}$ & 2,800 & 3,900 & 5,100 & 5,850 \\
\hline 6 & $\begin{array}{c}\text { Rumah } \\
\text { Tangga IV } \\
\text { (R4) }\end{array}$ & 3,350 & 4,650 & 5,850 & 6,600 \\
\hline 7 & $\begin{array}{c}\text { Instansi } \\
\text { Pemerintah } \\
\text { (R5) }\end{array}$ & 3,900 & 5,150 & 6,600 & 7,250 \\
\hline 8 & $\begin{array}{c}\text { Niaga } \\
\text { Kecil (B1) }\end{array}$ & 5,350 & 6,600 & 6,600 & 6,600 \\
\hline 9 & $\begin{array}{c}\text { Niaga } \\
\text { Besar (B2) }\end{array}$ & 5,600 & 7,250 & 7,250 & 7,250 \\
\hline 10 & $\begin{array}{c}\text { Industri } \\
\text { Kecil (B3) }\end{array}$ & 8,050 & 8,050 & 8,050 & 8,050 \\
\hline 11 & $\begin{array}{c}\text { Industri } \\
\text { Besar (B4) }\end{array}$ & 9,800 & 9,800 & 9,800 & 9,800 \\
\hline
\end{tabular}

\section{METODOLOGI PENELITIAN}

Sistem yang dibuat bertujuan untuk memonitoring data menggunakan WeMos, teknologi IoT dan dipantau langsung melalui gawai atau smartphone.

Penjelasan flowchart sesuai gambar 6 adalah dua buah sensor dan satu solenoid valve dipasang di aliran air PDAM. Sensor pertama digunakan untuk mengetahui nilai laju air sedangkan sensor kedua bertujuan untuk mengetahui kualitas air berdasarkan nilai derajat keasamannya.

Data yang diambil oleh sensor kemudian diolah di WeMos dan dikirimkan ke Firebase (cloud) agar bisa dipantau melalui internet via gawai. Aplikasi pada gawai merupakan antarmuka yang kemudian menampilkan data yang terdapat pada Firebase secara realtime kepada pengguna. Pengguna dapat mengubah nilai setpoint penggunaan air yang diinginkan. Apabila dalam mode kontrol dan nilai pemakaian melebihi nilai setpoint yang telah ditetapkan, maka solenoid valve akan menutup dan membuat laju aliran air berhenti. Informasi berupa tarif pemakaian dan banyaknya volume air yang dipakai diketahui dari aplikasi. 


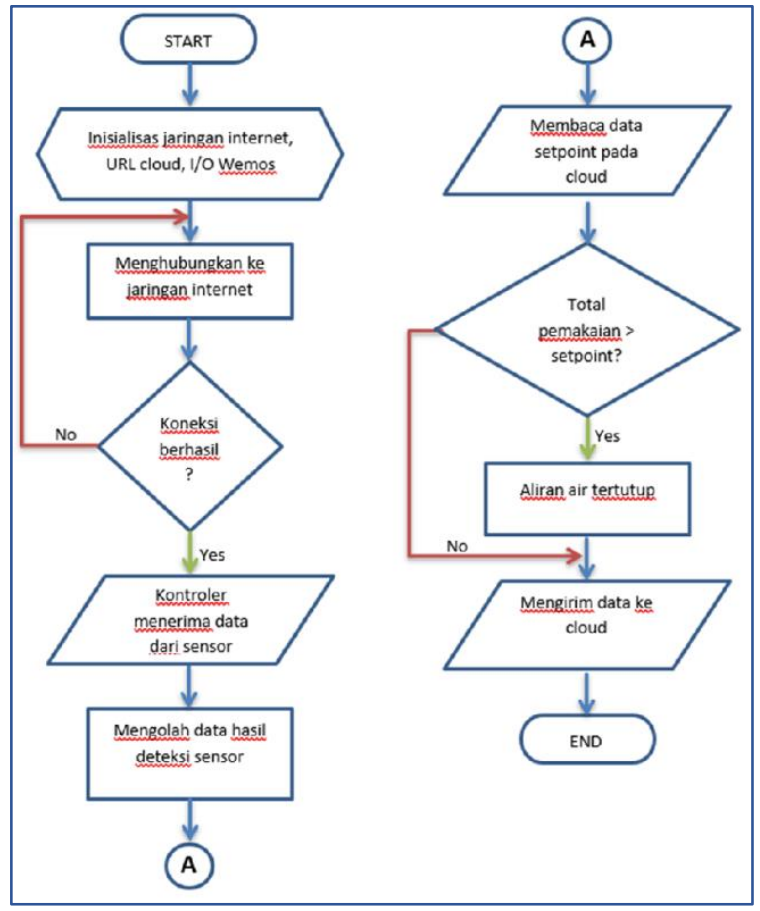

Gambar 6. Flowchart sistem

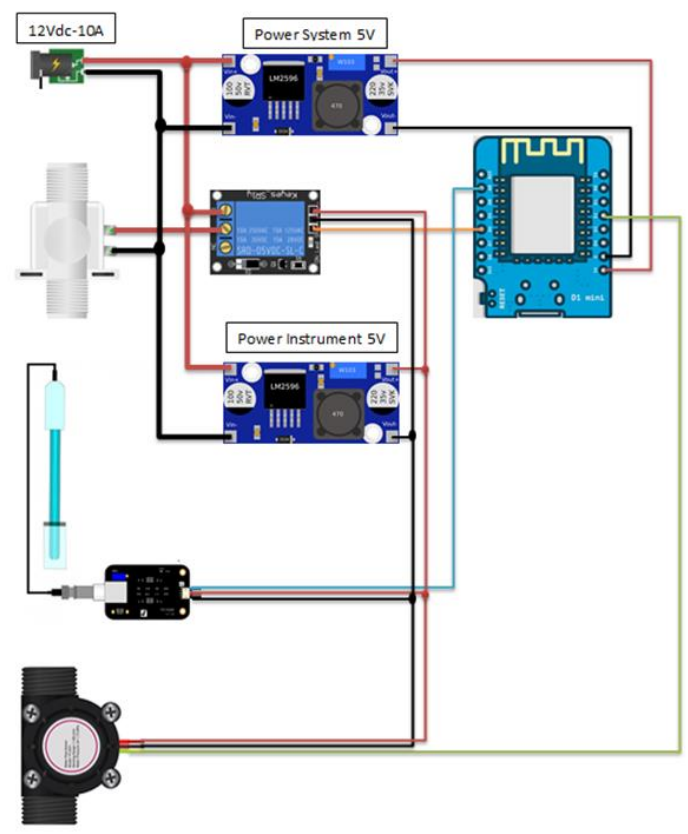

Gambar 7. Perancangan Sistem

Gambar 7 merupakan tampak rancangan sistem yang dibuat. Sistem menggunakan sumber daya utama dengan tegangan 12V dan Arus 10A (maksimum). Selanjutnya mengarah ke dua penurun tegangan (buck converter) berbasis switching. Bagian utma pada buck converter adalah switch controller dan daya. Kedua bagian ini dapat bekerja mengikuti mode CCM (Continuous Conduction Mode) atau DCM (Discontinuous Conduction Mode) tergantung dari bentuk sinyal pada arus induktor. Sebagai switching controller, umum digunakan move VMC (Voltage
Mode Controller) atau CMC (Current Mode Controller).

Kedua mode tersebut dapat diterapkan dengan baik dengan mengandalkan pulsa PWM (Pulse Width Modulation) maupun PFM (Pulse Frequency Modulation). PFM diyakini lebih efisien ketika arus pada beban cukup kecil. (Prithiba \& Laksmaiah, 2015) Dua penurun tegangan digunakan sebagai sumber daya pada mikrokontroler, relay dan sensorsensor. Jadi, penurun tegangan untuk mikrokontroler bebas dari pengaruh kerja komponen-komponen lainnya.

Tampak pada Gambar 8 merupakan tampilan aplikasi yang digunakan di gawai untuk monitoring penggunaan air, pengecekan kualitas air dan biaya yang dikeluarkan dalam Rupiah. Penggunaan dapat diketahui dari angka di bawah kata "Usage" kemudian kualitas air dapat diketahui dari angka yang tertera di bawah kata "Acidity". Selanjutnya, set point menandakan nilai yang dimasukkan ke dalam sistem untuk menetapkan banyaknya volume air yang akan dipergunakan dan diketahui jumlahnya.

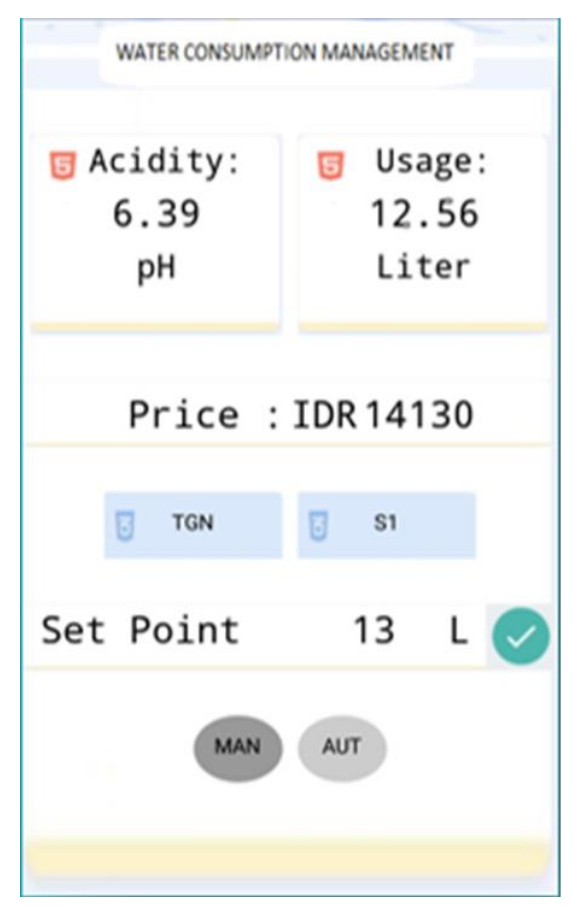

Gambar 8. Desain Antarmuka Aplikasi Pada Gawai

\section{HASIL DAN PEMBAHASAN}

Hasil penelitian berupa data-data pengujian dari berbagai sensor yang diterapkan pada sistem monitoring $\mathrm{pH}$ dan penggunaan air PDAM.

\section{Pengujian Sensor Flowmeter}

Sensor flowmeter mengeluarkan data dalam bentuk pulsa listrik berfrekuensi sehingga untuk mengetahui nilai aktual volume dan debit air, 
perlu dilakukan konversi data. Proses konversi data membutuhkan formula 1 s.d 5 di atas. Hasil setelah konversi terlihat pada tabel berikut ini:

Tabel 3. Data Karakteristik Sensor Sebelum Ditambah Nilai Kompensasi

\begin{tabular}{|c|c|c|c|}
\hline $\begin{array}{c}\text { Percobaan } \\
\text { Ke- }\end{array}$ & $\begin{array}{c}\text { Volume } \\
\text { Aktual } \\
(\mathrm{L})\end{array}$ & $\begin{array}{c}\text { Volume } \\
\text { Sebelum } \\
\text { ditambah 5\% (L) }\end{array}$ & $\begin{array}{c}\text { Error } \\
(\%)\end{array}$ \\
\hline 1 & 0,5 & 0,49 & 2 \\
\hline 2 & 0,5 & 0,46 & 8 \\
\hline 3 & 0,5 & 0,47 & 6 \\
\hline 4 & 1,0 & 0,94 & 6 \\
\hline 5 & 1,0 & 0,96 & 4 \\
\hline 6 & 1,0 & 0,94 & 6 \\
\hline 7 & 1,5 & 1,39 & 7,3 \\
\hline 8 & 1,5 & 1,38 & 8 \\
\hline 9 & 1,5 & 1,39 & 7,3 \\
\hline 10 & 2,0 & 1,89 & 5,5 \\
\hline 11 & 2,0 & 1,90 & 5 \\
\hline 12 & 2,0 & 1,88 & 6 \\
\hline \multicolumn{4}{|c|}{ Rata-rata } \\
\hline
\end{tabular}

Tabel 4. Data Karakteristik Sensor Sesudah Ditambah Nilai Kompensasi

\begin{tabular}{|c|c|c|c|}
\hline $\begin{array}{c}\text { Percobaan } \\
\text { Ke- }\end{array}$ & $\begin{array}{c}\text { Volume } \\
\text { Aktual } \\
(\mathrm{L})\end{array}$ & $\begin{array}{c}\text { Volume Setelah } \\
\text { ditambah 5\% (L) }\end{array}$ & $\begin{array}{c}\text { Error } \\
(\%)\end{array}$ \\
\hline 1 & 0,5 & 0,514 & 2,8 \\
\hline 2 & 0,5 & 0,483 & 3,4 \\
\hline 3 & 0,5 & 0,493 & 1,3 \\
\hline 4 & 1,0 & 0,987 & 1,3 \\
\hline 5 & 1,0 & 1,008 & 0,8 \\
\hline 6 & 1,0 & 0,987 & 1,3 \\
\hline 7 & 1,5 & 1,459 & 2,7 \\
\hline 8 & 1,5 & 1,449 & 3,4 \\
\hline 9 & 1,5 & 1,459 & 2,7 \\
\hline 10 & 2,0 & 1,984 & 0,8 \\
\hline 11 & 2,0 & 1,995 & 0,2 \\
\hline 12 & 2,0 & 1,974 & 1,3 \\
\hline \multicolumn{3}{|c|}{ Rata -Rata } & $\mathbf{1 , 8 3}$ \\
\hline
\end{tabular}

Nilai Volume Air Sebelum dan Sesudah Ditambah Kompensasi

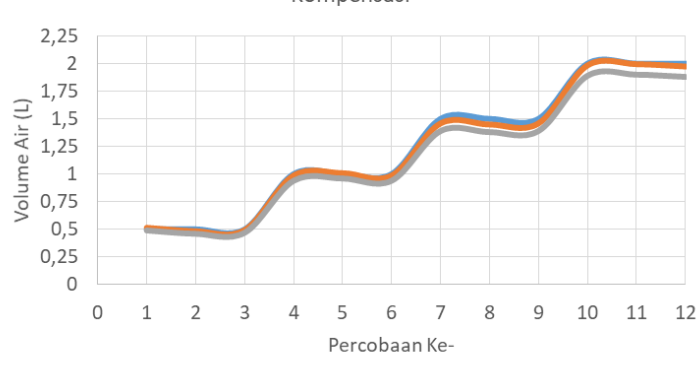

Volume Aktual (L) Volume Setelah ditambah 5\% (L)

Volume Sebelum ditambah 5\% (L)
Gambar 9. Grafik Perbandingan Volume Air Sebelum dan Sesudah Diberikan Nilai Kompensasi

Dari kedua tabel 3 dan 4 di atas ditambah dengan Gambar 9, data memperlihatkan bahwa sensor flowmeter harus dikalibrasi dengan menambahkan nilai kompensasi sebesar 5\% agar pembacaan volume mendekati nilai aktual. Oleh karena setelah diberikan tambahan niai kompensasi sebesar 5\%, maka nilai rata-rata error menjadi lebih kecil sekira $1,83 \%$ dari nilai yang diharapkan (setpoint).

\section{Pengujian Sensor $\mathrm{pH}$}

Luaran sensor $\mathrm{pH}$ berupa sinyal listrik dalam bentuk tegangan satuan Volt (DC). Nilai tegangan tersebut harus dikonversi menjadi nilai $\mathrm{pH}$ berdasarkan informasi pada tabel 1. Proses konversi data dilakukan di mikrokontroler dengan menggunakan relasi berikut:

$$
\begin{aligned}
& \frac{p H-4,01}{\text { tegangan }-4,82}=\frac{6,86-4,01}{4,02-4,82} \ldots \ldots \ldots \ldots \ldots \ldots \ldots \ldots . .7 \\
& p H-4,01=\frac{\text { tegangan } * 2,85-13,74}{-0,8} \ldots \ldots \ldots \ldots \ldots \ldots . . \\
& p H=21,176-3,562 * \text { tegangan } \ldots \ldots \ldots \ldots \ldots \ldots . .
\end{aligned}
$$

Selanjutnya, dengan menggunakan relasi no 9 di atas, pengujian sensor $\mathrm{pH}$ dapat dilakukan.

\begin{tabular}{|c|c|c|c|c|}
\hline \multirow{3}{*}{ No } & \multicolumn{2}{|c|}{6,86} & \multirow{2}{*}{\multicolumn{2}{|c|}{$\mathrm{pH}=6,86$}} \\
\hline & \multicolumn{2}{|c|}{$\mathrm{pH}=4,01$} & & \\
\hline & $\mathrm{pH}$ & Error & $\mathrm{pH}$ & Error \\
\hline 1 & 4,09 & $0,57 \%$ & 6,86 & $0,00 \%$ \\
\hline 2 & 4,09 & $0,57 \%$ & 6,86 & $0,00 \%$ \\
\hline 3 & 4,09 & $0,57 \%$ & 6,86 & $0,00 \%$ \\
\hline 4 & 4,09 & $0,57 \%$ & 6,86 & $0,00 \%$ \\
\hline 5 & 4,09 & $0,57 \%$ & 6,86 & $0,00 \%$ \\
\hline 6 & 4,09 & $0,57 \%$ & 6,86 & $0,00 \%$ \\
\hline 7 & 4,09 & $0,57 \%$ & 6,85 & $0,07 \%$ \\
\hline 8 & 4,10 & $0,64 \%$ & 6,86 & $0,00 \%$ \\
\hline 9 & 4,09 & $0,57 \%$ & 6,86 & $0,00 \%$ \\
\hline 10 & 4,09 & $0,57 \%$ & 6,82 & $0,29 \%$ \\
\hline 11 & 4,09 & $0,57 \%$ & 6,86 & $0,00 \%$ \\
\hline 12 & 4,10 & $0,64 \%$ & 6,86 & $0,00 \%$ \\
\hline 13 & 4,09 & $0,57 \%$ & 6,86 & $0,00 \%$ \\
\hline 14 & 4,10 & $0,64 \%$ & 6,86 & $0,00 \%$ \\
\hline 15 & 4,09 & $0,57 \%$ & 6,85 & $0,07 \%$ \\
\hline 16 & 4,09 & $0,57 \%$ & 6,85 & $0,07 \%$ \\
\hline 17 & 4,09 & $0,57 \%$ & 6,85 & $0,07 \%$ \\
\hline 18 & 4,10 & $0,64 \%$ & 6,86 & $0,00 \%$ \\
\hline 19 & 4,09 & $0,57 \%$ & 6,86 & $0,00 \%$ \\
\hline 20 & 4,09 & $0,57 \%$ & 6,86 & $0,00 \%$ \\
\hline & -rata & $0,58 \%$ & & $0,03 \%$ \\
\hline
\end{tabular}

Tabel 5. Pengujian Sensor $\mathrm{pH}$ untuk $\mathrm{pH}=4,01$ dan 6,86

Tabel 6. Pengujian Sensor $\mathrm{pH}$ untuk $\mathrm{pH}=9,18$ dan

\begin{tabular}{|c|c|c|c|c|}
\multicolumn{3}{|c|}{10,01} \\
\hline \multirow{2}{*}{ No } & \multicolumn{2}{|c|}{$\mathrm{pH}=9,18$} & \multicolumn{2}{c|}{$\mathrm{pH}=10,01$} \\
\cline { 2 - 5 } & $\mathrm{pH}$ & Error & $\mathrm{pH}$ & Error \\
\hline
\end{tabular}




\begin{tabular}{|c|c|c|c|c|}
\hline 1 & 9,10 & $0,57 \%$ & 10,07 & $0,43 \%$ \\
\hline 2 & 9,10 & $0,57 \%$ & 10,08 & $0,50 \%$ \\
\hline 3 & 9,11 & $0,50 \%$ & 10,09 & $0,57 \%$ \\
\hline 4 & 9,11 & $0,50 \%$ & 10,11 & $0,71 \%$ \\
\hline 5 & 9,11 & $0,50 \%$ & 10,12 & $0,79 \%$ \\
\hline 6 & 9,11 & $0,50 \%$ & 10,12 & $0,79 \%$ \\
\hline 7 & 9,10 & $0,57 \%$ & 10,12 & $0,79 \%$ \\
\hline 8 & 9,11 & $0,50 \%$ & 10,12 & $0,79 \%$ \\
\hline 9 & 9,11 & $0,50 \%$ & 10,12 & $0,79 \%$ \\
\hline 10 & 9,12 & $0,43 \%$ & 10,12 & $0,79 \%$ \\
\hline 11 & 9,11 & $0,50 \%$ & 10,12 & $0,79 \%$ \\
\hline 12 & 9,11 & $0,50 \%$ & 10,11 & $0,71 \%$ \\
\hline 13 & 9,11 & $0,50 \%$ & 10,12 & $0,79 \%$ \\
\hline 14 & 9,11 & $0,50 \%$ & 10,12 & $0,79 \%$ \\
\hline 15 & 9,11 & $0,50 \%$ & 10,10 & $0,64 \%$ \\
\hline 16 & 9,12 & $0,43 \%$ & 10,11 & $0,71 \%$ \\
\hline 17 & 9,11 & $0,50 \%$ & 10,10 & $0,64 \%$ \\
\hline 18 & 9,10 & $0,57 \%$ & 10,11 & $0,71 \%$ \\
\hline 19 & 9,11 & $0,50 \%$ & 10,11 & $0,71 \%$ \\
\hline 20 & 9,11 & $0,50 \%$ & 10,12 & $0,79 \%$ \\
\hline \multicolumn{2}{|c|}{ Rata - rata } & $0,51 \%$ & & $0,71 \%$ \\
\hline
\end{tabular}

Dari hasil pengujian sensor $\mathrm{pH}$ untuk tujuan karakterisasi, didapatkan hasil error rata-rata $<1 \%$. Nilai error rata-rata terbesar terdapat pada kolom pengujian sensor dengan $\mathrm{pH}$ 10,01 sedangkan yang terkecil pada pengujian dengan $\mathrm{pH}$ 6,86. Tampilan lebih jelasnya seperti terlihat pada gambar 10 .

Asumsi dari nilai error rata-rata yang terkecil memberikan gambaran peluang untuk untuk pengujian pada rentang $\mathrm{pH}$ larutan dengan sifat netral. Rentang nilai $\mathrm{pH}$ netral merupakan salah satu karakteristik air bersih. Sehingga sensor sangat sesuai jika digunakan untuk pemantauan nilai $\mathrm{pH}$ air bersih.

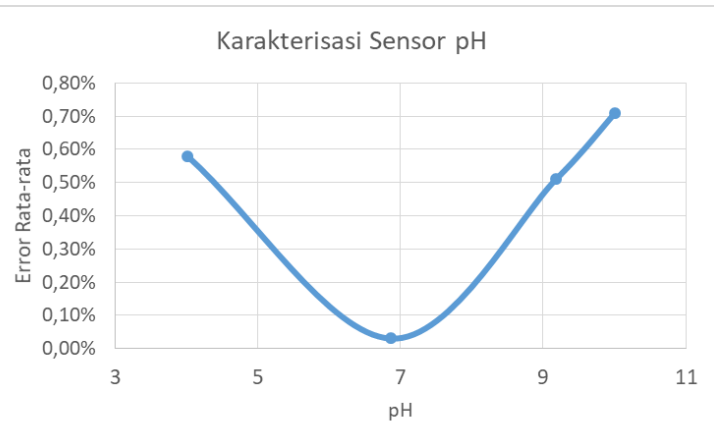

Gambar 10. Nilai error rata-rata terhadap pH

3. Respon Alat Terhadap Setpoint

Tabel 7 merupakan data hasil percobaan antara nilai setpoint pemakaian air yang telah ditetapkan dan volume air yang mengalir setelah aliran air tertutup. Terlihat pada kolom error terdapat nilai tertinggi sebesar 3,65\% dan nilai error total rata-rata sebesar $1,29 \%$. Nilai error yang besar ini tidak selalu muncul, hanya terdapat di beberapa tempat. Nilai overshoot dapat saja terjadi akibat aliran arus air yang tidak stabil. Oleh karena itu desain arah dan kecepatam aliran fluida sangat perlu diperhatikan.

Tabel 7. Data Perbandingan Antara Volume Air Setpoint dan Aktual

\begin{tabular}{|c|c|c|c|}
\hline $\begin{array}{c}\text { Percobaan } \\
\text { ke - }\end{array}$ & $\begin{array}{c}\text { Volume Air } \\
\text { Setpoint (L) }\end{array}$ & $\begin{array}{c}\text { Volume Air } \\
\text { Aktual (L) }\end{array}$ & Error \\
\hline 1 & 15 & 15,16 & $1,07 \%$ \\
\hline 2 & 15 & 15,24 & $1,60 \%$ \\
\hline 3 & 15 & 15,52 & $3,47 \%$ \\
\hline 4 & 20 & 20,20 & $1,00 \%$ \\
\hline 5 & 20 & 20,25 & $1,25 \%$ \\
\hline 6 & 20 & 20,73 & $3,65 \%$ \\
\hline 7 & 30 & 30,22 & $0,73 \%$ \\
\hline 8 & 30 & 30,13 & $0,43 \%$ \\
\hline 9 & 30 & 30,32 & $1,07 \%$ \\
\hline 10 & 40 & 40,22 & $0,55 \%$ \\
\hline 11 & 40 & 40,17 & $0,43 \%$ \\
\hline 12 & 40 & 40,29 & $0,72 \%$ \\
\hline 13 & 50 & 50,10 & $0,20 \%$ \\
\hline 14 & 50 & 50,83 & $1,66 \%$ \\
\hline 15 & 50 & 50,77 & $1,54 \%$ \\
\hline \multicolumn{4}{|c|}{ Rata-rata } \\
\hline
\end{tabular}

\section{KESIMPULAN}

Sensor flowmeter harus ditambah nilai kompensasi agar mendekati nilai yang diharapkan. Setelah dilakukan karakterisasi, sensor $\mathrm{pH}$ yang digunakan pada penelitian ini sangat sesuai untuk memonitor kualitas air bersih. Tampilan layar aplikasi pada gawai sudah menunjukkan nilai yang mendekati kesesuaian antara setpoint dengan volume air aktual terpakai. Nilai error rata-rata pada respon alat khususnya pada volume air terhadap niai setpoint yang telah ditetapkan sudah berada pada nilai yang kecil namun masih perlu diperkecil lagi. Kedepannya penelitian ini dapat dikembangkan dengan menambahkan kemampuan untuk mengukur penggunaan air dan tarifnya di banyak wilayah dalam jaringan distribusi PDAM.

\section{REFERENSI}

Amanda, G. (2019, Agustus 15). Republika.co.id. Retrieved from Khazanah: https://republika.co.id/berita/nasional/daerah/ pwgp3m368/dunia-

islam/wakaf/19/08/15/pwa9j7423-

kekeringan-melanda-puluhan-juta-jiwaterancam

Arief Rachman Hakim, D., Budijanto, A., \& Widjanarko, B. (2018, 12 20). Sistem Monitoring Penggunaan Air PDAM pada Rumah Tangga Menggunakan Mikrokontroler NODEMCU Berbasis Smartphone Android. 
IPTEK Media Komunikasi Teknologi, 22(2), 9-18. doi:10.31284/j.iptek.2018.v22i2.259

Aryanto, F. A. (2019). Rancang Bangun Kontrol dan Monitoring Meteran Air PDAM Berbasis Internet of Things. Surabaya: Universitas Dinamika. Retrieved from http://repository.dinamika.ac.id/id/eprint/363 5/1/15410200046-2019STIKOMSURABAYA.pdf

Barus, E., Ch Louk, A., \& Pinggak, R. (2018, Agustus). Otomatisasi Sistem Kontrol pH dan Informasi Suhu Pada Akuarium Menggunakan Arduino Uni dan Raspberry PI 3. Jurnal Fisika Sains dan Aplikasinya, 3(2).

Br Pelawi, S., \& Manan, S. (2016, Oktober). Sistem Monitoring Volume Air Menggunakan Sensor Ultrasonik dan Monitoring Output Volume Air Menggunakan Flowmeter Berbasis Arduino. Gema Teknologi, 19(2).

Dr. Adhyatma, M. (1990). PERATURAN MENTERI KESEHATAN No: 416/Men.Kes/Per/IX/1990 Tentang Syarat-syarat dan Pengawasan Kualitas Air. Jakarta: Kementerian Kesehatan Republik Indonesia.

Mondal, D. (2019). The Internet of Things (IoT) and Industrial Automation: A Future Perspective. World Journal Modelling and Simulation, 15(2), 140-149. Retrieved from https://www.researchgate.net/publication/336 552020

Prithiba, D., \& Laksmaiah, K. (2015). Design of DCDC BUck Converter for Airborne Radar Applications. International Journal \& Magazine of Engineering, Technology, Management and Research, 2(3), 28-33.

Purwanto, E. W. (2020, Juni). Pembangunan Akses Air Bersih Pasca Krisis Covid-19. The
Indonesian Journal of Development Planning, $\operatorname{IV}(2)$.

Rudiansyah, A., Mardiono, \& Diharja, R. (2020). Desain Alat Monitoring Kapasitas Tabung Gas LPG 3 Kilogram Menggunakan Load Cell Dilengkapi Dengan Deteksi Kebocoran Gas Berbasis Internet of Things. Bumigora Information Technology (BiTe), 131-138.

Satriya, F., Mardiono, \& Diharja, R. (2020). Rancang Bangun Alat Monitorinh Suhu Tubuh Untuk Pasien Demam Berdarah Menggunakan Smartphone Berbasis Internet of Things. Bumigora Information Technology (BiTe), 113-118.

Setiadi, D., \& Abdul Muhaemin, M. (2018, Desember). Penerapan Internet of Things (IoT) Pada sistem Monitoring Irigasi (Smart Irigasi). Infotronik, 3(2).

Supplies, P. (2020). ESP8266 D1 R2 WiFi Processor with Uno Footprint. Retrieved from Proto Supplies:

https://protosupplies.com/product/esp8266d1-r2-wifi-processor-with-uno-footprint/

Tameson. (2020). Tameson . Retrieved from Solenoid Valve - How They Work: https://tameson.com/solenoid-valvetypes.html

USGS. (2019). pH and Water. Retrieved from USGS Science for changing world: https://www.usgs.gov/special-topic/waterscience-school/science/ph-and-water?qtscience_center_objects $=0$ \#qtscience_center_objects 